\title{
Toxoplasma gondii and Neospora caninum in domestic cats from the Brazilian semi-arid: seroprevalence and risk factors
}

\author{
[Toxoplasma gondii e Neospora canimum em gatos no semiárido nordestino: \\ soroprevalência e fatores de risco] \\ T.F. Feitosa ${ }^{1}$, V.L.R. Vilela ${ }^{1}$, E.S. Dantas ${ }^{2}$, D.V.O. Souto ${ }^{1}$, H.F.J. Pena ${ }^{3}$, \\ A.C.R. Athayde ${ }^{1}$, S.S. Azevêdo ${ }^{1}$ \\ ${ }^{1}$ Aluno de pós-graduação - Universidade Federal de Campina Grande - UFCG - Patos, PB \\ ${ }^{2}$ Universidade Federal de Campina Grande - UFCG - Patos, PB \\ ${ }^{3}$ Faculdade de Medicina Veterinária e Zootecnia - Universidade de São Paulo - São Paulo, SP
}

\begin{abstract}
In the present study we aimed to establish the seroprevalence of $T$. gondii and $N$. caninum in stray and domiciled cats from the municipality of Patos, Paraíba state, Brazil. Blood samples were collected from 201 animals: 132 domiciled cats and 69 stray cats. An epidemiological questionnaire was conducted with all cat owners. Indirect immunofluorescent antibody test (IFAT) was performed at cut-offs of 1:16 and 1:50 for $T$. gondii and $N$. caninum, respectively. Overall prevalence of seroreagent cats for $T$. gondii was $43.8 \%$. We found a prevalence of $47.7 \%$ in domiciled cats and $36.2 \%$ in stray cats. Antibody titers ranged from 1:16 (cut-off) to $1: 8192 ; 1: 128$ was the most frequent titer. No statistical difference was observed between domiciled cats and stray cats. Correlation was verified between seroreagent for $T$. gondii and age and hunting habit $(\mathrm{P}<0.05)$. No animals tested seroreagent for $N$. caninum. It was possible to conclude that there is high prevalence of cat seroreagent for $T$. gondii and that $N$. caninum is not present in cats from the area studied.
\end{abstract}

Keywords: domiciled cat, stray cat, toxoplasmosis, zoonosis

\section{RESUMO}

Este trabalho teve como objetivo determinar frequência de Toxoplasma gondii e Neospora caninum em gatos domiciliados e errantes do município de Patos, mesorregião do sertão paraibano. Foram coletadas amostras de sangue provenientes de 201 gatos, 132 domiciliados e 69 errantes. Nos domiciliados, foi aplicado um questionário epidemiológico aos proprietários. A reação de imunofluorescência indireta (RIFI) foi realizada levando-se em consideração os pontos de corte 1:16 e 1:50 para T. gondii e N. caninum, respectivamente. Foi obtida uma prevalência total de $43.8 \%$ de gatos sororreagentes para $T$. gondii. Nos domiciliados, a prevalência foi de 47,7\% (63/132), e nos errantes de 36,2\% (25/69), com títulos variando de 1:16 a 1:8192, sendo a titulação 1:128 a mais frequente. Não se observou diferença estatística entre animais domiciliados e errantes. Verificou-se correlação entre sororreagentes a T. gondii e idade e hábito de caçar $(P<0.05)$. Nenhum animal foi sororreagente para $N$. caninum. Concluiuse que é alta a prevalência de gatos sororreagentes para T. gondii e que o N. caninum não está presente em gatos na área estudada.

Palavras-chave: gatos domiciliados, gatos errantes, toxoplasmose, zoonose

\section{INTRODUCTION}

Toxoplasma gondii is a protozoan able to infect humans and several warm-blooded animals
(Dubey, 2004), and cats play an important role in the transmission of the agent, because they are the only hosts capable of eliminating oocysts in the environment, being responsible for the natural cycle of the disease (Dubey and Beatle,

Recebido em 25 de março de 2013

Aceito em 17 de dezembro de 2013

E-mail: feitosa_tf@yahoo.com.br 
1988). Cats are able to eliminate about 20 million oocysts between three and 18 days post infection (Dabritz et al., 2007). Serological studies in such animals are used to estimate the environmental contamination, considering that oocysts are rarely found in feces (Dubey et al., 1995; Miró et al., 2004).

Neospora caninum is an obligate intracellular protozoan that has dogs, coyotes and dingoes as definitive hosts (Dubey et al., 2007; King et al., 2010). Although there is no documented case report of natural infection with $N$. caninum in cats, experimental infection has already been performed in these animals (Dubey and Lindsay, 1989). There is little information on the seroprevalence of $N$. caninum in cats in Brazil, being observed only in the state of São Paulo, with frequencies ranging from 11.9 to $24.5 \%$ (Dubey et al., 2002; Bresciani et al., 2007), and in the state of Maranhão, with prevalence of $27 \%$ (Braga et al., 2012).

Several works have been carried out on $T$. gondii and $N$. caninum infection in pigs, goats, and sheep (Araújo Neto et al., 2008; Azevedo et al., 2010; Faria et al., 2010) from the semiarid mesoregion of northeastern Brazil, but no research was carried out to determine the status of these agents in cats. Thus, in the present study, we aimed to determine the frequency of seroreagent for $T$. gondii and $N$. caninum and possible risk factors in domiciled and stray cats in the municipality of Patos, Paraíba state.

\section{MATERIAL AND METHODS}

This survey was conducted in the municipality of Patos $\quad\left(7^{\circ} 13\right.$ 'S, $\left.\quad 37^{\circ} 16^{\prime} \mathrm{W}\right)$, Paraíba state, northeastern Brazil, between May and August 2011. No probabilistic criteria were used for the selection of domiciled animals: the choice was dependent on owner consent. Blood samples were collected from 201 animals: 132 domiciled cats and 69 stray cats. Collection was made by jugular vein puncture and the blood was centrifuged to obtain serum and subsequently stored at $-20{ }^{\circ} \mathrm{C}$ until processing of analyzes.
The experiments conducted in this work comply with current regulations in Brazil and were approved by the Research Ethics Committee of UFCG, protocol 27-2012.

Indirect immunofluorescence assay (IFAT) was used to detect antibodes anti-T. gondii and antibodes anti- $N$. caninum using cut-offs of $1: 16$ and 1:50, respectively (Cruz et al., 2011, Dubey 1988). In order to detect antibotes anti- $T$. gondii, we used RH strain tachyzoides of $T$. gondii fixed on slides (Camargo 1974); while for the detection of $N$. caninum, $\mathrm{Nc}-1$ tachyzoide samples fixed on slides were utilized (Dubey et al., 1988). Conjugated anti-cat IgG (SIGMA, St. Louis, MO, USA) was used for both agents.

The frequency of antibodes anti-T. gondii and anti- $N$. caninum was estimated from the ratio of positive results for the total number of cats examined, with exact binomial confidence interval of $95 \%$ (Thrusfield, 2004), using EpiInfo, version 6.04. The association between wandering domiciled animals regarding the frequency of positivity was verified by the Chisquare test (Zar, 1999), with a significance level of $5 \%$.

An epidemiological questionnaire was conducted with the owners of domiciled cats concerning the following issues: age, sex, type of food, access to street environment, place where animals live and defecate, and hunting habit. We used the information obtained from the questionnaires in the analysis of risk factors, which was conducted in two phases: univariate analysis and multivariate analysis. For the univariate analysis, each independent variable was matched with the dependent variable, and those that presented $\mathrm{p} \leq$ 0.20 value by the Chi-square test or Fisher's exact test were selected for multivariate analysis, using multiple logistic regression. The final model fit was verified by the Hosmer Lemeshow test, whose $\mathrm{P}>0.05$ value indicates a good fit (Hosmer and Lemeshow, 2000). A significance level of $5 \%$ was adopted for the multivariate analysis. All analyses were performed with SPSS 20.0 for Windows. 


\section{RESULTS}

Eighty-eight $(43.8 \%, 95 \% \mathrm{CI}=36.8 \%-50.9 \%)$ of the 201 examined cats were seroreagent for $T$. gondii. For stray cats, $25(36.2 \%, 95 \% \mathrm{CI}=$ $25.0 \%-48.7 \%)$ of the 69 animals were seroreagent. For domiciled cats, $63(47.7 \%, 95 \%$ $\mathrm{CI}=38.9 \%-56.6 \%)$ of the 132 animals were seroreagent. There was no statistical difference between stray and domiciled cats regarding the frequency of seropositivity $(\mathrm{p}=0.159)$. No animals were seropositive for $N$. caninum in this study.

The titers of antibodies to $T$. gondii ranged from 16 to 8192 , with 128 and 2048 being the most frequent in stray animals. This variation was also observed in domiciled cats, with greater frequency of titers: 128, 1024, and 2048 (Table 1).

Table 1. Prevalence of antibodies anti-Toxoplasma gondii by IFAT in 201 sera from domiciled and stray cats in Paraíba State, Northeast region of Brazil, at different dilutions

\begin{tabular}{|c|c|c|c|}
\hline \multirow{2}{*}{ Titer } & \multicolumn{2}{|c|}{ Seroreagent animals } & \multirow{2}{*}{$\begin{array}{c}\text { Total } \\
(\%)\end{array}$} \\
\hline & Number of stray cats (\%) & Number of domiciled cats (\%) & \\
\hline 16 & $3(12)$ & $3(4.8)$ & $6(6.8)$ \\
\hline 32 & $2(8)$ & - & $2(2 ; 3)$ \\
\hline 64 & $1(4)$ & $6(9.5)$ & $7(7.9)$ \\
\hline 128 & $5(20)$ & $10(15.9)$ & $15(17)$ \\
\hline 256 & $2(8)$ & $9(14.3)$ & $11(12.5)$ \\
\hline 512 & $3(12)$ & $4(6.4)$ & $7(7.9)$ \\
\hline 1024 & $3(12)$ & $10(15.9)$ & $13(14.8)$ \\
\hline 2048 & $4(16)$ & $10(15.9)$ & $14(15.9)$ \\
\hline 4096 & - & $8(12.7)$ & $8(9)$ \\
\hline 8192 & $2(8)$ & $3(4.8)$ & $5(5 ; 7)$ \\
\hline Total & $25(100)$ & $63(100)$ & $88(100)$ \\
\hline
\end{tabular}

Results from univariate analysis of risk factors for $T$. gondii are shown in Table 2. The variables age, type of food, and hunting habit were selected $(\mathrm{P} \leq 0.20)$ for multivariate analysis. The following variables were identified as risk factors by logistic regression (Table 3): age 1-4 years (odds ratio $=4.85)$, age $>4$ years $($ odds ratio $=$ 16.54), and hunting habit (odds ratio $=2.43$ ). The final model showed satisfactory fit by the Hosmer - Lemeshow test (Chi-square $=2248, \mathrm{P}$ $=0.690)$.

\section{DISCUSSION}

The high frequency of seroreagent cats found $(43.8 \%)$ indicates that there is considerable environmental contamination by oocysts, suggesting that cats play a prominent role in the epidemiology of toxoplasmosis in the area studied. The high contamination is a concern because it favors the appearance of disease outbreaks in humans and animals due to contamination of water and food supplies, or even by inhalation (Dubey et al., 2004; Carmo et al., 2010).

Different from the results found in this study, Rosa et al. (2010) and Cruz et al. (2011) found low prevalence of $T$. gondii in southern Brazil, attributing this result to the way animals were raised, since most of them presented strictly domiciled habits and ingested only industrialized products. In this research, most of the animals had access to the street and did not consume only industrialized food $(71.2 \%)$. 
Toxoplasma gondii and Neospora caninum...

Table 2. Univariate analysis for association between the presence of anti-Toxoplasma gondii antibodies and risk factors in cats from Paraíba State, Brazil

\begin{tabular}{|c|c|c|c|}
\hline Variable & Number of cats & Seroreagent cats (\%) & $P$ \\
\hline \multicolumn{4}{|l|}{ Sex } \\
\hline Males & 72 & $33(45.8)$ & \\
\hline Females & 60 & $30(50)$ & 0.762 \\
\hline \multicolumn{4}{|l|}{ Age (years) } \\
\hline $0-1$ & 42 & $8(19)$ & \\
\hline $1-4$ & 66 & $36(54.5)$ & \\
\hline$>4$ & 24 & $19(79.2)$ & $<0.001$ \\
\hline \multicolumn{4}{|l|}{ Type of food } \\
\hline Industrialized & 48 & $15(31.2)$ & \\
\hline Industrialized + meat & 84 & $48(57.1)$ & 0.007 \\
\hline \multicolumn{4}{|l|}{ Access to the street } \\
\hline No & 36 & $16(44.4)$ & \\
\hline Yes & 96 & $47(49.0)$ & 0.790 \\
\hline \multicolumn{4}{|l|}{$\begin{array}{l}\text { Environment where } \\
\text { animals live }\end{array}$} \\
\hline Land & 80 & $38(47.5)$ & \\
\hline Ceramic & 52 & $25(48.1)$ & 1.000 \\
\hline \multicolumn{4}{|l|}{ Where animals defecate } \\
\hline Sand box & 31 & $13(41.9)$ & \\
\hline In the street & 101 & $50(49.5)$ & 0.594 \\
\hline \multicolumn{4}{|l|}{ Hunting habit } \\
\hline No & 52 & $18(34.6)$ & \\
\hline Yes & 80 & $45(56.2)$ & 0.024 \\
\hline
\end{tabular}

Table 3. Final logistic regression model for risk factors associated with Toxoplasma gondii in cats from Paraíba State, Brazil.

\begin{tabular}{ccc}
\hline Variable & Odds ratio $($ IC 95\%) & P \\
\hline Age 1-4 years old & $4,85(1.92-12.25)$ & 0.001 \\
Age > 4 years old & $16,54(4.61-59.28)$ & 0.001 \\
Hunting habit & $2,43(1.08-5.42)$ & 0.031 \\
\hline
\end{tabular}

Hosmer and Lemeshow test: chi-square $=2.248 ; \mathrm{P}=0.690$

One can infer that the prevalence rates observed in this and other surveys depend on several factors, including the techniques and cut-off points adopted. There are no experiments in cats standardizing the cut-off, and there is no data for $T$. gondii in cats in the studied region, so we preferred to use a cut-off according to Garcia et al. (1999), Lucas et al. (1999), Pinto et al. (2009) and Cruz et al. (2011). The lack of standardization of diagnostic techniques complicates the comparison of results. Many studies work with different cut-offs. In the state of Maranhão, Braga et al. (2012) used IFAT with a cut-off of 1:40, observing prevalence of $50.5 \%$.
In the state of Santa Catarina, Rosa et al. (2010) used a cut-off of 1:64 and obtained $14.33 \%$ prevalence. Other researchers used different techniques, such as Indirect Hemagglutination Test and Modified Agglutination Test, noting prevalence between $26.9 \%$ and $35.4 \%$ (Pena et al., 2006; Pinto et al., 2009). In this study there was no statistical difference in positivity between domiciled and stray cats, probably because most of the domiciled cats in this study have free access to the street, also being exposed to the agent. DeFeo et al. (2002) also found no difference between these categories. However, several authors indicate that stray cats tend to 
present higher prevalence when compared to domiciled cats (Miró et al., 2004; Raeghi et al., 2011).

Regarding the sex variable, no difference was observed in either domiciled or stray animals, indicating that the genders have an equal chance of being seroreagent for $T$. gondii, corroborating other authors that obtained the same results in their researches (Rosa et al., 2010; Cruz et al., 2011).

The majority of animals showed seroresgent titer $\geq 128$. With the titration of $\mathrm{IgG}$, it is only possible to suggest that infection is recent or active when it presents titers above 256 , and that infection is latent when titers are below 256 (Lappin, 2004). Bresciani et al. (2007) reported that titers above 1024 strongly indicate that the animal is asymptomatically infected with Toxoplasma or presenting clinical signs; 27 animals presented titers above 1024 in this work.

The age variable was considered a risk factor for the presence of antibodies for T. gondii., corroborating the works by Miró et al. (2004), Pena et al. (2006) and Pinto et al. (2009). This association can be explained by the fact that older animals are more likely to become infected because they have been exposed more often. However, some authors found no difference regarding this variable in their studies (Cruz et al., 2011).

Studies show that access to the street is a risk factor for the seroreagent of cats (Pena et al., 2006; Rosa et al., 2010), but, in this research, none of the possible risk factors, such as access to the street, place where animals defecate, and environment where animals live were significant for $T$. gondii infection.

The prevalence of antibodies in animals that fed only on industrialized products was $31.1 \%$, while the animals that consumed meat with processed feed had a prevalence of $57.1 \%$, with positive association in the univariate analysis. The hunting habit variable was also significant for $T$. gondii. These results can be explained by the biology of the parasite, since one of its routes involves the formation of bradyzoites in the tissues of animals; cats can then become infected by the ingestion of tissues containing the parasite. Raeghi et al. (2010) also observed positive association between meat intake and positivity of cats.

Corroborating this work, Arunvipas et al. (2012) found no animals seroreagent for $N$. caninum. However, Dubey et al. (2002) made the first detection of positive cats in the world, by natural infection with $N$. caninum, in a study carried out in Brazil, São Paulo State. Positive animals and positive correlation between $T$. gondii and $N$. caninum were found in other studies conducted in Brazil. In Maranhão State, $27 \%$ of seropositive animals were found, and in São Paulo state there was $24.5 \%$ (Bresciani et al. 2007; Braga et al., 2012). There are only a few reports on naturally acquired seropositivity and studies on $N$. caninum in cats is limited (Hornok et al., 2008; Bresciani et al., 2007). There is need for further research to elucidate the role of cats in the epidemiology of this disease, and to find out whether this parasite can harm the health of these animals.

\section{CONCLUSION}

We conclude that the prevalence of seroreagent cats for T. gondii is high and that there are no differences in seropositivity of domiciled and stray cats. The age and hunting habit are significant risk factors for infection by this parasite. The presence of $N$. caninum was not observed in the studied animals.

\section{REFERENCES}

ARAÚJO NETO, J.O; AZEVEDO, S.S.; GENNARI, S. et al. Prevalence and risk factors for anti-Toxoplasma gondii antibodies in goats of the Seridó Oriental microregion, Rio Grande do Norte state, Northeast region of Brazil. Vet. Parasitol., v.156, p.329-332, 2008.

ARUNVIPAS, P.; INPANKAEW, T.; JITTAPALAPONG, S. Risk factors of Neospora caninum infection in dogs and cats in dairy farms in Western Thailand. Trop. Anim. Health Prod., v.44, p.1117-1121, 2012.

AZEVEDO, S.S.; PENA, H.F.J.; ALVES, C.J. et al. Prevalence of anti-Toxoplasma gondii and anti-Neospora caninum antibodies in swine from Northeastern Brazil. Rev. Bras. Parasitol. Vet., v.19, p.1-5, 2010. 
BRAGA, M.S.C.O.; ANDRÉ, M.R.; JUSI, M.M.G. Occurrence of anti-Toxoplasma gondii and anti-Neospora caninum antibodies in cats with outdoor acess in São Luís, Maranhão, Brazil. Rev. Bras. Parasitol. Vet., v.21, p.107111, 2012.

BRESCIANI, K.D.S.; GENNARI, S.M.; SERRANO, A.C.M. et al. Antibodies to Neospora caninum and Toxoplasma gondii in domestic cats from Brazil. Parasitol. Res., v.100, p.281-285, 2007.

CAMARGO, M.E. Introdução as técnicas de imunofluorescência. Rev. Bras. Patol. Clín., v.10, p.87-107, 1974.

CARMO, E.L.; POVOA, M.M.; MONTEIRO, N.S.S. et al. Surto de toxoplasmose humana no Distrito de Monte Dourado, Municipio de Almeirim, Pará, Brasil. Rev. Pan-Amaz. Saúde, v.1, p.61-66, 2010.

CRUZ, M.A.; ULLMANN, L.S.; MONTAÑO, P.Y. et al. Seroprevalence of Toxoplasma gondii infection in cats from Curitiba, Paraná, Brazil. Rev. Bras. Parasitol. Vet., v.20, p.256-258, 2011.

DABRITZ, H.A.; MILLER, M.A.; ATWILL, E.R. et al. Detection of Toxoplasma gondii like oocysts in cat feces and estimates of the environmental oocyst burden. J. Am. Vet. Med. Assoc., v.231, p.1676-1684, 2007.

DEFEO, M.L.; DUBEY, J.P.; MATHER, T.N.; RHODES, R.C. Epidemiologic investigation of seroprevalence of antibodies to Toxoplasma gondii in cats and rodents. Am. J. Vet Res., v.63, p.1714-1717, 2002.

DUBEY, J.P. Toxoplasmosis - a waterborne zoonosis. Vet. Parasitol., v.126, p.57-72, 2004.

DUBEY, J.P.; BEATTIE, C.P. (Eds). Toxoplasmosis of animals and man. Florida: CRC PRESS, 1988. 220 p.

DUBEY, J.P.; CARPENTER, J.L.; SPEER, C.A. Newly recognized fatal protozoan disease of dogs. J. Am. Vet. Med. Assoc., v.192, p.12691285, 1988.

DUBEY, J.P.; LINDSAY, D.S. Transplacental Neospora caninum infection in cats. $J$. Parasitol., v.75, p.765-771, 1989.
DUBEY, J.P.; LINDSAY, D.S.; HILL, D. et al. Prevalence of contrabodies to Neospora caninum and Sarcocystis neurona in sera of domestic cats from Brazil. J. Parasitol., v.88, p.1251-1252, 2002.

DUBEY, J.P.; SCHARES, G.; ORTEGAMORA, L.M. Epidemiology and control of neosporosis and Neospora caninum. Clin. Microbiol. Rev., v.20, p.323-367, 2007.

DUBEY, J.P.; WEIGEL, R.M.; SIEGEL, A.M. et al. Sources and reservoirs of Toxoplasma gondii infection on 47 swine farms in Illinois. $J$. Parasitol., v.81, p.723-729, 1995.

FARIA, E.B.; CAVALCANTI, E.F.T.S.F.; MEDEIROS, E.S. et al. Risk factors associated with Neospora caninum seroreagent in sheep from the State of Alagoas, in the Northeast Region of Brazil. J. Parasitol., v.26, p.197-199, 2010.

GARCIA, J.L.; NAVARRO, I.T.; OGAWA, L. et al. Soroepidemiologia da toxoplasmose em gatos e cães de propriedades rurais do município de Jaguapitã, estado do Paraná. Brazil. Ciên. Rural, v.29, p.99-104, 1999.

HORNOK, S.; EDELHOFER, R.; JOACHIM, A. et al. Seroprevalence of Toxoplasma gondii and Neospora caninum infection of cats in Hungary. Acta Vet. Hung., v.56, p.81-8, 2008.

HOSMER, D.W.; LEMESHOW, S. (Eds.). Applied logistic regression. New York: John Wiley \& Sons, 2000. 375 p.

KING, J.S.; SLAPETA, J.; JENKINS, D.J. et al. Australian dingoes are definitive hosts of Neospora caninum. Int. J. Parasitol., v.40, p.945-950, 2010.

LAPPIN, M.R., (Ed.) Infecções Protozoárias e Mistas. In: ETTINGER, S.J., FELDMAN, E.C. (Eds.). Tratado de Medicina Interna Veterinária. Rio de Janeiro: Guanabara, 2004. 433-435p.

LUCAS, S.R.R.; HAGIWARA, M.K.; LOUREIRO, V.S. et al. Toxoplasma gondii infection in brazilian domestic outpatient cats. Rev. Inst. Med. Trop., v.41, p.221-226, 1999.

MIRÓ, M.; MONTOYA, A.; JIMÉNEZ, S. et al. Prevalence of contrabodies to Toxoplasma gondii and intestinal parasites in stray, farm and household cats in Spain. Vet. Parasitol., v.126, p.249-255, 2004. 
PENA, H.F.J.; SOARES, R.M.; AMAKU, M. et al.. Toxoplasma gondii infection in cats from São Paulo state, Brazil: seroprevalence, oocyst shedding, isolation in mice, and biologic and molecular characterization. Res. Vet. Scienc., v.81, p.58-67, 2006.

PINTO, L.D.; ARAÚJO, F.A.P.; STOBBE, N.S.; MARQUES, S.M.T. Soroepidemiologia de Toxoplasma gondii em gatos domiciliados atendidos em clínicas particulares de Porto Alegre, RS, Brasil. Cienc. Rural., v.39, p.24642469, 2009.
RAEGHI, S.; SEDEGHI, S. Prevalence of Toxoplasma gondii antibodies in cats in Urmia, Northwest of Iran. J. Anim. Plant Sci., v.21, p.132-134, 2011.

ROSA, L.D.; MOURA, A.B.; TREVISANI, N. et al. Toxoplasma gondii antibodies on domiciled cats from Lages municipality, Santa Catarina State, Brazil. Rev. Bras. Parasitol. Vet., v.19, p.268-269, 2010

THRUSFIELD, M. (Ed.). Epidemiologia Veterinária. São Paulo: Roca, 2004. p.556.

ZAR, J.H., (Ed.) Biostatistical analysis. New Jersey: Prentice Hall, 1999. p.663. 